\title{
Psychological resources, satisfaction, and career identity in the work transition: an outlook on Sicilian college students
}

This article was published in the following Dove Press journal:

Psychology Research and Behavior Management

\section{Giuseppe Santisi' \\ Paola Magnano ${ }^{2}$ \\ Silvia Platania' \\ Tiziana Ramaci²}

'Department of Educational Sciences, University of Catania, Catania, Italy;

${ }^{2}$ Faculty of Human and Social Sciences,

"Kore" University of Enna, Enna, Italy
Correspondence: Giuseppe Santisi Department of Educational Sciences, University of Catania, Via Biblioteca, 4, Catania (CT), Sicily 95100 , Italy

Tel +390952508020

Email gsantisi@unict.it
Background: The phases of career building today bring out a more complex process than in previous decades. Starting from the literature review, the university-to-work transition is considered a very important step in the future career of the graduates, and it involves some psychological resources and requires specific abilities.

Methods: Research has examined the psychological resources that students at the end of a degree course can use in the university-to-work transition. The aim of the study is to verify the relationship between academic satisfaction and career identity, and the mediational role of readiness and confidence on this relationship. A group of 438 students were assigned to complete a questionnaire in order to examine the relationship between academic satisfaction and career identity and the role of core components of psychological resources: readiness and confidence as mediator.

Results: The results indicated both a direct relationship between academic satisfaction and career identity and a mediated relationship with the influence of readiness and confidence for a transition. Adding to our results, we assert that academic satisfaction has a directed effect on confidence during the transition and is a predictor of career identity, both directly and by the mediation of readiness in career transitions.

Conclusion: Career identity has implication for exploratory behavior, thus increasing the motivation and mindfulness that create a virtuous circle, influencing the development of knowledge and skills, which are the base of proactivity and confidence in construction of one's future career. Keywords: career, transition, identity, satisfaction, resources

\section{Introduction}

The university-to-work transition is a fundamental step in the construction of a career identity for graduates. ${ }^{1}$ This progression has changed drastically over the past 20 years. The exit from college is the beginning of the transition to the working world, probably the first of many career transitions, which will require varying degrees of coping skills and adaptability over time. ${ }^{2}$ In fact, leaving student life behind and beginning a new life as a full-time employee require important career-related decisions that can determine graduates' future career success. ${ }^{3}$

Today, young graduates approaching the labor market are undoubtedly more exposed to the inherent uncertainty of the current economic situation. In the last decade, because of the economic crisis, in Europe the employment rate of young persons (age group 20-29) 28 is $61.4 \%$; in Italy it is 40.3, with a decrease of about $14 \%$ from 2004 to $2015(53.5 \%) .{ }^{4}$ We highlight two of the numerous factors that make today's transition 
to work more complex than it was in the past: the processes of social change, such as globalization and internationalization of markets, are redesigning the structure of life and labor content, which leads to increased mobility and career paths being often unpredictable, ${ }^{5}$ and the creation of new forms of work produces different expectations regarding the required professional skills, social skills, and learning in new situations. This affects the career decisions taken. Individuals can often be exposed to numerous complex vocational choices, which in turn may lead to risky situations, such as difficult transitions, social exclusion, education, and employment, or even paths that can lead to unemployment or poverty. ${ }^{6}$ According to Koen et al, ${ }^{7}$ a way of enhancing a successful transition from the educational phase to the work is that of a proper vocational training, as better preparation can help individuals to seek and successfully find employment, improving the career outcomes. ${ }^{8-10}$

Thus, considering that occupational mobility has become increasingly common ${ }^{11}$ and the concept of having a job for life has been replaced by a myriad of alternatives, such as vocational retraining, job sharing, and flex-time, ${ }^{12}$ a successful career transition in this scenario depends overall on an individual's capacity to manage the different demands relating to the transition and, particularly, the demands on their psychological resources. ${ }^{13}$ Consequently, the career notion itself requires a new definition, leaving the traditional view as a gradual movement upward within a hierarchical structure. ${ }^{14}$ It is characterized by instability, flexibility, and capacity to move across different working roles, going beyond the boundaries of a single employment setting. ${ }^{15}$ These characteristics involve processes identified as career transitions in which workers disengage from their previous situation and engage in new situations. ${ }^{16}$ Considering the importance the career transition has in the broader life project, the present study focused its attention on the role that psychological resources play in career transitions and the way in which academic satisfaction affects career identity. The aim of the study presented is verifying the mediational role that psychological resources have in the relationship between academic satisfaction and career identity.

\section{Literature review}

\section{The university-to-work transition and the} psychological resources

The university-to-work transition can be included in career transition, which is defined as "the period in which an individual objectively takes on a different role and/or subjectively changes his or her orientation to a role" (p. 385). ${ }^{12}$
Literature about university-to-work transition has explored the sociodemographic (gender, nationality, school-type), personality (openness, locus of control), and career development variables (career decidedness, career planning) in relation to perceived chance events, ${ }^{17}$ other studies deepened the job involvement, ${ }^{18}$ or are focused on specific target as NEET (Not in Education, Employment, or Training), ${ }^{19}$ or on specific interventions, as training ${ }^{7}$ and career counseling. ${ }^{1,20}$ Finally, the most recent contributions focus on entrepreneurship propensity of outgoing students from the academic path. ${ }^{21-23}$

As emphasized by Fernandez et al, ${ }^{12}$ each type of "career transition requires a reorientation of goals, attitudes, identity, and vocational and behavioral routines" (p. 386) as well as many other large or subtle changes. ${ }^{14}$ The reaction to the changes is based on the individual, as even though career transitions may have become the standard in the professional world, there is not a common way in which people experience these situations because each individual has his or her own resources and barriers. ${ }^{12}$ In reviewing individual characteristics, the career-counseling literature has focused increasingly on the psychological resources involved in the career-transition process. The psychological resources involved in career decision-making processes include hope, optimism, ${ }^{24}$ self-efficacy, extraversion, commitments, and values. The core components of psychological resources to face career transitions effectively are readiness and confidence ${ }^{14,25}$ readiness indicates how individuals are motivated to make a career transition; confidence assesses how able a person feels about completing the tasks required for a successful career transition. Motivation and confidence are related to greater job satisfaction, lower levels of stress, and a greater degree of control in adults undergoing career changes. ${ }^{25}$ Moreover, the readiness is related to the ability to take advantage of opportunities and to deal with barriers and setbacks in the domain of career choice. ${ }^{26,27}$ Therefore, the career choice-related self-efficacy beliefs have been shown to positively associate with career exploration ${ }^{28,29}$ and career persistence. ${ }^{30}$ Low self-efficacy has been shown to be linked with career indecision ${ }^{31}$ and fear of commitment. ${ }^{32}$

\section{The role of career identity in university-to-work transitions}

In their literature analysis, $\mathrm{Ng}$ and Feldman ${ }^{33}$ emphasized that a successful university-to-work transition requires individuals to change from the student role to the work role as their core life role. ${ }^{34}$ A successful study-to-work transition was characterized in young adults by high levels of identification with the work role. Career identity is not linked to a particular work 
role or work place but derives its meaning from a sequence of work-related experiences; it consists of individual dispositions (such as attributes, beliefs, values, motives, and experiences) that represent the way individuals define themselves in the context of a career, and can be conceptualized as a "cognitive compass" ${ }^{35}$ used to navigate career opportunities. ${ }^{36}$ During career transitions, the capacity to leverage one's career identity as a guide when establishing goals and making decisions may be critical in identifying career opportunities.

Bergami and Bagozzi ${ }^{37}$ applied the social identity theory in a work and organization context, proposing new measures for the cognitive (i.e., self-categorization) component of identification. The authors began with the conceptualization of organization identification, which is a form of social identification whereby a person comes to view him- or herself as a member of a particular social entity, the organization. ${ }^{38}$ This occurs through the cognitive processes of categorization in which there are categories of organizational membership and similarities and differences with members of other organizations. ${ }^{39}$ Considering that the literature about the role of career identity in school-to-work is not exhaustive, we can hypothesize that in university-to-work transitions, the identification process can occur with a professional category rather than an organizational role, constructing social identity through the self-awareness of belonging to the professional category.

\section{The relationship between academic satisfaction and university-to-work transition}

Defining satisfaction as the degree of congruence between aspirations and perceived experience, Rust and Oliver ${ }^{40}$ proposed the expectancy-disconfirmation paradigm (EDP), a model describing the process by which consumers form judgments about products or services by using their prior expectations about the characteristics or benefits offered by the given product or service. As highlighted by Zehrer et al, ${ }^{41}$

There are three possible outcomes of the consumer evaluative process $[\ldots]$ : the consumer, according to EDP, may find the product/service worse than expected [negative disconfirmation], better than expected [positive disconfirmation], or as expected [confirmation]. [p. 106]

We can find a large number of studies in the area of educational marketing that apply the paradigm to student satisfaction, ${ }^{42,43}$ considering students' satisfaction with their educational experience similar to customer satisfaction toward the services offered by the educational organizations. Satisfaction in career transitions occurs in different ways and at different steps of the process. Literature about adolescents' career development over the last 10 years emphasizes that the satisfaction in school and university choices, derived from opportunities to use various skills and interests and to implement one's self-concept, ${ }^{44}$ can be linked to positive development in youth ${ }^{45}$ and, more specifically, ${ }^{46-48}$ positive career orientation and better career preparation. ${ }^{49}$

Even though satisfaction is considered an outcome of the career decision-making process, ${ }^{50}$ in the context of career choices in which we analyze the transition from a university student to a competent worker, the degree of satisfaction of the previous stage can provide information about identification with the succeeding profession. Similarly, Blanch and Aluja ${ }^{18}$ in their study found that satisfaction with the university courses was predictive of job involvement during the transition from university to a job situation.

Even though literature has already deepened the issues presented, in our review we have not found works that analyze the relationship between academic satisfaction and career identity, and the role of psychological resources in this relationship: the study presented below is an attempt to fill this gap and to indicate some practical implication of these relationships.

\section{Aims of the study}

Starting from the literature review presented above, the university-to-work transition is considered a very important step in the future career of the graduates, and it involves some psychological resources and requires specific abilities. ${ }^{51}$ Among these resources that can facilitate career transition, career choice, and career decision making, the present study focused on those considered the core components of psychological resources, readiness, and confidence. Research on students' satisfaction in the EDP perspective highlighted, among the others, some individual antecedents of the students' satisfaction $;{ }^{42}$ moreover, Nurmi et $\mathrm{al}^{52}$ explored the relationship between psychological resources and academic satisfaction and dissatisfaction. Then, considering that satisfaction is a significant predictor of positive outcomes in several spheres of life, we hypothesize that there is a direct effect between academic satisfaction and career identity and that readiness and confidence mediate the effect of this relationship (indirect effects).

- Hypothesis 1: The perceived academic satisfaction will be positively related to career identity.

- Hypothesis 2: Readiness and confidence will mediate the relationship between academic satisfaction and career identity. 


\section{Methods}

\section{Participants and procedures}

In this cross-sectional study, a total of 451 students were surveyed, from November 2016 to May 2017, and all participants were asked to complete a paper questionnaire, which was administered to 438 students ( $97 \%$ response rate), whereas $3 \%(n=13)$ of the students refused to participate in the survey, owing to lack of time needed to reply to questions. The participants had already completed the first level of bachelor's degree (3 years), were enrolled at the second level (2 years), and were attending the final year of their academic career at the University of Catania. Participants were informed about the study aims and procedures and gave their written informed consent to participate.

Participation in the study was completely voluntary, and data were collected anonymously with a self-report paper questionnaire; filling in the questionnaire took about 15-20 minutes, and participants could refuse participation at any point in the study. Research procedures were complied with the ethical guidelines and Code of Conduct of the American Psychological Association, Italian Psychological Association, and University of Catania and approved by the internal review board (IRB) of Faculty of Human and Social Sciences at the "Kore" University of Enna.

Table 1 presents the demographic characteristics: $26.2 \%$ were enrolled in political sciences, $24.2 \%$ in the school of law, $24.9 \%$ in medicine and paramedical professions, and
$24.7 \%$ in psychology. The mean age of the participants was $23.61(\mathrm{SD}=1.3)$.

\section{Measures}

\section{Career transition inventory (CTI)}

The $\mathrm{CTI}^{25,53}$ is a 40 -item Likert scale that measures the perception of the psychological resources available to individuals who are experiencing a career transition. The CTI is composed of five dimensions: career motivation (readiness), self-efficacy (confidence), perceived support (support), internal-external (control), and self versus relational focus (decision independence). The scale shows good psychometric properties: Cronbach's alpha reported by authors comprised values from 0.66 to 0.87 ; total scale alpha coefficient is $0.85 .{ }^{12}$ For the aims of our study, we have chosen the following subscales:

Readiness: This subscale (13 items) measures individuals' motivation to move forward with the career transition. Sample item: "The risks of this career transition are high but I am willing to take the chance". Participants responded on a five-point scale ranging from strongly disagree to strongly agree. In our study Cronbach's coefficient alpha was 0.87 .

Confidence: This subscale (11 items) measures the level of self-efficacy on individual tasks that students face to successfully go through the work transition. Sample item: "I don't feel much internal 'push' to work hard at this career transition". Participants responded on a five-point scale

Table I Demographic profile of the sample for each course of study

\begin{tabular}{|c|c|c|c|c|c|c|c|c|c|c|}
\hline & \multicolumn{10}{|c|}{ Course of study } \\
\hline & \multicolumn{2}{|c|}{ Political sciences } & \multicolumn{2}{|c|}{ Law } & \multicolumn{2}{|c|}{$\begin{array}{l}\text { Medicinel } \\
\text { paramedical }\end{array}$} & \multicolumn{2}{|c|}{ Psychology } & \multicolumn{2}{|c|}{ Total } \\
\hline & $\bar{f}$ & $\%$ & $f$ & $\%$ & $\bar{f}$ & $\%$ & $f$ & $\%$ & $f$ & $\%$ \\
\hline Participants & 115 & 26.2 & 106 & 24.2 & 109 & 24.9 & 108 & 24.7 & 438 & 100.0 \\
\hline \multicolumn{11}{|l|}{ Gender } \\
\hline Male & 55 & 47.8 & 30 & 28.3 & 55 & 50.5 & 25 & 23.1 & 165 & 37.7 \\
\hline Female & 60 & 52.2 & 76 & 71.7 & 54 & 49.5 & 83 & 76.9 & 273 & 62.3 \\
\hline Total & 115 & 100.0 & 106 & 100.0 & 109 & 100.0 & 108 & 100.0 & 438 & 100.0 \\
\hline \multicolumn{11}{|l|}{ Age (years) } \\
\hline $23-25$ & 107 & 93.0 & 106 & 100.0 & 108 & 99.1 & 101 & 93.5 & 422 & 96.3 \\
\hline $26-29$ & 8 & 7.0 & 0 & 0.0 & 1 & 0.9 & 4 & 3.7 & 13 & 3.0 \\
\hline Over 29 & 0 & 0.0 & 0 & 0.0 & 0 & 0.0 & 3 & 2.8 & 3 & 0.7 \\
\hline Total & 115 & 100.0 & 106 & 100.0 & 109 & 100.0 & 108 & 100.0 & 438 & 100.0 \\
\hline \multicolumn{11}{|l|}{ Income } \\
\hline Up to $30,000.00 €$ & 87 & 75.7 & 49 & 46.2 & 82 & 75.2 & 89 & 82.4 & 307 & 70.1 \\
\hline$>30.000,00 €$ & 27 & 23.5 & 43 & 40.6 & 27 & 24.8 & 19 & 17.6 & 116 & 26.5 \\
\hline \multicolumn{11}{|l|}{$<70.000,00 €$} \\
\hline Over $70.000,00 €$ & I & 0.8 & 14 & 13.2 & 0 & 0.0 & 0 & 0.0 & 15 & 3.4 \\
\hline Total & 115 & 100.0 & 106 & 100.0 & 109 & 100.0 & 108 & 100.0 & 438 & 100.0 \\
\hline
\end{tabular}


ranging from strongly disagree to strongly agree. In our study Cronbach's coefficient alpha was 0.85 .

\section{Academic satisfaction}

This scale was built specifically for this study and was founded on the EDP. ${ }^{54,55}$ According to this paradigm, the user compares the perception of performance service with previous expectations. If expectations are confirmed or exceeded, the user is satisfied. However, if the expectations are believed by the perceived performance, the user is dissatisfied. Satisfaction, thus, depends upon the size and direction of the process of denial defined as the difference between expectations and performance as perceived by the user. The first phase of the study focused on the exploration of a qualitative matrix aimed at generating a first list of objects capable of providing a synthesis of the theoretical domain of satisfaction of university students. For this purpose, a content analysis was conducted that allowed us to identify some keywords that allowed us to build 12 items that perceived satisfaction. The first step was a reliability analysis based on total correlation, considering the cutoff of $0.40 .{ }^{56}$ It was then proceeded to eliminate the items placed below the cutoff. Subsequently, the Kaiser-Meyer-Olkin sampling adequacy test and Barlett's sphericity test were calculated to evaluate the suitability of the exploratory factorial analysis. Consistent with previous studies, for the purposes of item selection, only the loading factors $>0.50^{57}$ were considered, thus eliminating those items below that threshold value. The final scale consists of the following four items and measures students' satisfaction concerning their activities at the university: "I am satisfied because I have had the opportunity to learn new skills/knowledge"; "I am glad we chose this academic path"; "I am satisfied with the choice because I like what I studied"; "I am satisfied because my degree course corresponds to the future". Participants responded on a fivepoint scale ranging from very unlikely to very likely. In our study Cronbach's coefficient alpha was 0.91 .

\section{Career identity}

To evaluate career identity we have chosen the Inclusion of the Other in the Self method, ${ }^{58}$ a single-item scale adapted to the aim of the study, ${ }^{37}$ composed of a handy pictorial instrument for measuring the subjectively perceived closeness of a relationship. ${ }^{59}$ Participants were asked to express the relationship between two identities ("those who work in your field of study" and "yourself"), evaluating their opinion on a seven-point scale from widely separated to completely overlapped.

\section{Data analyses}

Linear structural equation models were calibrated to test the hypothesized model AMOS 21.0. ${ }^{60}$ First, a confirmatory factor analysis (CFA) was used to test the model fit of the measurement model. ${ }^{61}$ The SEM approach was then used to test the mediation model following James et al's recommendations ${ }^{62}$ and Shrout and Bolger's ${ }^{63}$ logic in regard to expected proximal and distal effects. Other well-known analytical tools, such as correlations, were also used, which were implemented by using SPSS 20.0. To optimize the sample size, missing values for the relevant items were estimated using expectation maximization method. None of the items had $>5 \%$ missing values, indicating that this option was appropriate for use. ${ }^{64}$

\section{Results \\ Preliminary analysis}

A CFA was used to test the fit of the measurement model. ${ }^{61}$ To verify the adequacy of the models, we used $\chi^{2}$. Given that this statistic is sensitive to sample size, the two-index strategy ${ }^{65}$ that entails the combined use of the comparative fit index ${ }^{66}$ CFI - and standardized root mean square residual was used.

The results indicated that the readiness, confidence, and satisfaction of a one-factor structure fit the data, particularly for readiness, $\chi^{2}(65)=761.099, p<0.001$, root mean square of approximation (RMSEA) $=0.08$, goodness-of-fit index $(\mathrm{GFI})=0.90$, comparative fit index $(\mathrm{CFI})=0.94$, normed fit index $(\mathrm{NFI})=0.92$; confidence, $\chi^{2}(35)=399.345, p<0.001$, $\mathrm{RMSEA}=0.08$, GFI $=0.91, \mathrm{CFI}=0.95, \mathrm{NFI}=90$; and satisfaction, $\chi^{2}(2)=3.477, p<0.001$, RMSEA $=0.04$, GFI $=1.00$, $\mathrm{CFI}=0.99, \mathrm{NFI}=0.99$.

\section{Mediating effects of readiness}

The means, SDs, and interrelations between constructs are reported in Table 2 . The results showed that satisfaction correlates positively with readiness and career identity. Furthermore, readiness correlates positively with confidence and career identity. Moreover, the demographic variable of age correlates negatively with variable confidence, while the gender demographic variable indicates that female gender is more inclined to develop career identity.

To test the mediating effects of readiness, the bootstrapping procedure proposed by Hayes ${ }^{67}$ was used.

The results show that (Figure 1) 1) satisfaction predicts career identity (hypothesis $1, \beta=0.32, \mathrm{R} 2=0.10, p<0.001$ ); 2 ) satisfaction predicts readiness $(\beta=0.38, \mathrm{R} 2=0.05, p<0.001)$; $3)$ satisfaction predicts confidence $(\beta=0.32, \mathrm{R} 2=0.08$, $p<0.05)$; 4) the effect of satisfaction on career identity is 
Table 2 Means, SDs, and correlations among study variables

\begin{tabular}{|c|c|c|c|c|c|c|c|c|c|}
\hline Variables & $\mathbf{N}$ & Mean & SD & Alpha & I & 2 & 3 & 4 & 5 \\
\hline Satisfaction & 438 & 3.16 & 0.670 & 0.91 & 1 & & & & \\
\hline Readiness & 438 & 4.38 & 0.717 & 0.87 & $0.379 * *$ & 1 & & & \\
\hline Confidence & 438 & 3.13 & 0.750 & 0.85 & $0.131 *$ & $0.157 * *$ & I & & \\
\hline Career identity & 438 & 3.16 & 0.670 & - & $0.411 * *$ & $0.353^{* *}$ & & I & \\
\hline Gender & 438 & - & - & - & & & & $-0.097^{*}$ & I \\
\hline Age & 438 & 23.61 & 1.30 & - & & & $-0.186 * *$ & & \\
\hline
\end{tabular}

Note: ${ }^{*} p<0.01 ;{ }^{* *} p<0.05$.

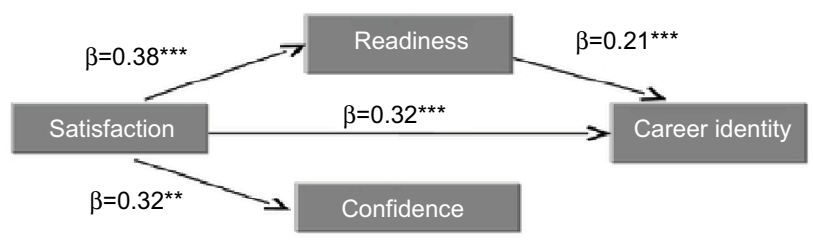

Figure I Summary of the research model proposed (the values shown are estimates of regression coefficients).

Note: $*^{*} p<0.05$ and $* * * p<0.00$ I.

reduced after controlling for readiness (hypothesis $2, \beta=0.23$, $\mathrm{R} 2=0.09, p<0.05$; and indirect effect $=0.21 ; p<0.001$ ), which was also tested using the bootstrap method ${ }^{67,68}$ conducted in 2000 bootstrap samples with a CI of $95 \%$, indicating that there is a partial mediation $(\mathrm{SE}=0.006,95 \% \mathrm{CI}=0.018$, 0.050). Conversely, confidence does not mediate the relationship between academic satisfaction and career identity.

\section{Discussion}

This study aimed to analyze and understand whether and how much the academic satisfaction in a group of students was related to career identity and if the internal psychological resources that occur during this transition affect this relationship. Compared to the mediation, the results suggest a positive relationship between the perceived academic satisfaction and the construction of career identity; satisfaction also correlates positively with confidence.

In addition, the readiness (the proactive attitude toward the career construction) plays an important role in the relationship between perceived academic satisfaction and career identity, revealing, however, that internal psychological resources are decisive in affecting transitions, especially in university-to-work transitions. This means that the students who are more satisfied with their academic choice - who are aware that the courses they attended were coherent with their professional interests, values, and expectations - will likely be motivated to move forward with the career transition; moreover, these students seem to be ready to face their university-to-work transition effectively, and will develop a career identity that is not necessarily linked to a particular work role or workplace but derives its meaning from a significant and satisfactory university experience. As highlighted by Blanch and Aluja, ${ }^{18}$ satisfaction with the university courses is predictive of a significant job adjustment during the transition to a job situation from university; these findings are similar to the results of Wong et al. ${ }^{69}$ So, the identification with the career prepared during the university course, facilitated by the readiness in dealing with the university-to-work transition, will allow the students to acquire the ability to process feedback about the self and achieve self-awareness ${ }^{70}$ and improve the ability to interact with the complexity of their work environments. As reported by previous studies, in fact, academic satisfaction is related with future job adjustment in many ways: it is related positively with job involvement, ${ }^{18}$ task significance, task identity, feedback, and autonomy, ${ }^{69}$ and negatively to turnover intent. ${ }^{71}$ Adding to our results, we assert that academic satisfaction has a directed effect on confidence during the transition and is a predictor of career identity, both directly and by the mediation of readiness in career transitions. Career identity, as stated previously, is the "internal career compass", ${ }^{35}$ and it is particularly important in providing direction and in facilitating the adaptation to changing factors that are critical at all stages of one's career path, especially during the transitions. A career or professional identity also affects individual organizational behavior in the workplace, showing a positive relationship with performance outcomes, such as career success. Finally, professional identification is associated with several important organizational outcomes, such as affective commitment and work satisfaction. ${ }^{72,73}$

Conversely, the students who have not developed this "internal compass" probably will face with the university-towork transition with more difficulties in finding a meaningful career and a meaningful job.

\section{Conclusion and limitation}

The findings of the study lead us to believe that a career identity in line with individuals' own studies can affect the well-being of the individuals, thus increasing the motivation 
and mindfulness that create a virtuous circle, influencing the development of knowledge and skills, which are the base of proactivity and confidence in construction of one's future career. This consideration is even truer in contextualizing the career-constructing process in relation to the constraints and economic and social problems that are present in some regions of Italy. Several areas of southern Italy have extremely critical macroeconomic indicators, high unemployment, and low industrial development, therefore requiring further effort toward the structuring of appropriate career-counseling services.

According to marketing education's approaches, the study presented offers interesting suggestions to increase the value of the university as organization. In fact, among the dimensions analyzed, which have proved to be very relevant in the construction of the career identity, we are convinced that there are two areas that can be improved in the academic institutions. Regarding academic satisfaction, it would be necessary to plan and improve the services according to the needs of students in order to meet their academic expectations. In regard to the core dimensions for career transition, readiness and confidence should be included in the interventions planned by career-counseling and job-placement services. In fact, we strongly believe that, first, tutoring activities, focused on a career counseling's perspective, should be to develop the students' awareness of their abilities and skills; then, the activities of job placement could favor vocations of the students to guide them toward a meaningful choice and a meaningful work.

More specifically, the career-counseling services should implement their interventions toward two directions: 1) monitoring the degree of students' satisfaction during their academic career because high levels of satisfaction prevent them from dropping out and are related with academic success; moreover, high levels of academic satisfaction contribute to a coherent career identity; 2) developing psychological resources, such as proactivity, ${ }^{74}$ emotional intelligence, ${ }^{75,76}$ resilience, ${ }^{77}$ courage ${ }^{78,79}$ and mindfulness, ${ }^{80-82}$ readiness, career adaptability, ${ }^{83}$ and career identity through specific career-counseling or career-education programs. These interventions could contribute to helping students, after completing their degree, become more aware of their resources and able to face the numerous future transitions.

The research presented has some limitations that could be suggestions for future works: first, the cross-sectional nature of the study does not allow the monitoring of the degree of satisfaction during the academic attendance; second, the study does not make a comparison between groups with invariance for the equality factor because the sample taken was not homogeneous; and, moreover, future studies could involve more groups and those coming from different backgrounds and fields of study. In particular, the sample of the study has a prevalence of female students, which probably could affect the results: an extension of this study could involve a gender-paired sample and could make a comparison between the results. Another critical point linked to the sampling regards the degree courses attended by the participants: probably some of them prepare the students to a clearer and definite career (e.g., medicine), while others have not clear professional paths (e.g., political science), and this could affect the development of the career identity; in future studies, a better-balanced sampling regarding the degree courses will allow to explore the differences from this point of view.

Despite these limitations, however, the results provide important suggestions on future research and interventions, for example in the ex-post-evaluation of the effectiveness of these intervention modes, not only in terms of satisfaction but also as employability of graduates.

\section{Disclosure}

The authors report no conflicts of interest in this work.

\section{References}

1. Krumboltz JD, Worthington R. The school-to-work transition from a learning theory perspective. $C D Q$. 1999;47(4):312-326.

2. Murphy L, Denis R, Ward CP, Tartar JL. Academic stress differentially influences perceived stress, salivary cortisol, and immunoglobulin-A in undergraduate students. Stress. 2010;13(4):366-371.

3. Saks AM, Gruman JA. What do we really know about employee engagement? HRDQ. 2014;25:155-182.

4. Eurostat. Employment statistics. 2017 [www Document]. Available from: http://ec.europa.eu/eurostat/data/database; http://www.pssru. ac.uk/. Accessed February 22, 2018.

5. Masdonati J, Massoudi K, Rossier J. Effectiveness of career counseling and the impact of working alliance. J Career Dev. 2009;36: 183-203.

6. Creed PA, Muller J, Patton W. Leaving high school: the influence and consequences for psychological well-being and career-related confidence. J Adolesc. 2003;26(3):295-311.

7. Koen J, Klehe U, Van Vianen AEM. Training career adaptability to facilitate a successful school-to-work transition. $J$ Vocat Behav 2012;81(3):395-408.

8. Hirschi A, Niles SG, Akos P. Engagement in adolescent career preparation: social support, personality and the development of choice decidedness and congruence. J Adolesc. 2011;34(1):173-182.

9. Jepsen DA, Dickson GL. Continuity in life-span career development: career exploration as a precursor to career establishment. $C D Q$. 2002;51(3):217-233.

10. Koivisto P, Vinokur AD, Vuori J. Effects of career choice intervention on components of career preparation. CDQ. 2011;59(4):345-366.

11. Briscoe JP, Hall DT, Frautschy DeMuth RL. Protean and boundaryless careers: an empirical exploration. J Vocat Behav. 2006;69, 30-47.

12. Fernandez A, Fouquereau E, Heppner MJ. The career transition inventory. A psychometric evaluation of a French version (CTI-F). J Career Assess. 2008;16(3):384-398. 
13. Cairo PC, Kritis KJ, Myers RM. Career assessment and the adult career concerns inventory. J Career Assess. 1996;4(2):189-204.

14. Ashforth BE, Saks AM. Work-role transitions: a longitudinal examination of the Nicholson model. J Occup Organ Psychol. 1995;68(2):157-175.

15. De Fillippi RJ, Arthur MB. Boundaryless contexts and careers: a competency-based perspective. In: Arthur MB, Rousseau DM, editors. The Boundaryless Career: A New Employment Principle for a New Organizational Era. New York: Oxford University Press; 1996:116-131.

16. Allen VL, van de Vliert E. Role Transitions: Explorations and Explanations. New York: Plenum Press; 1984.

17. Hirschi A. The role of chance events in the school-to-work transition: the influence of demographic, personality and career development variables. J Vocat Behav. 2010;77(1):39-49.

18. Blanch A, Aluja A. Job involvement in a career transition from university to employment. Learn Individ Differ. 2010;20(3):237-241.

19. Bynner J, Parsons S. Social exclusion and the transition from school to work: the case of young people Not in Education, Employment, or Training (NEET). J Vocat Behav. 2001;60(2):289-209.

20. Lent R, Worthington RL. Applying career development theories to the school-to-work transition process. CDQ. 1999;47(4):291-296.

21. Dehghanpour Farashah A. The process of impact of entrepreneurship education and training on entrepreneurship perception and intention. J Educ Train Stud. 2013;55(8/9):868-885.

22. Morris M, Webb JW, Fu J, Singhal S. A competency-based perspective on entrepreneurship education: conceptual and empirical insights. J Small Bus Manag. 2013;51(3):352-369.

23. Sesen H. Personality or environment? A comprehensive study on the entrepreneurial intentions of university students. J Educ Train Stud. 2013;55(7):624-640.

24. Magnano P, Paolillo A, Giacominelli B. Dispositional optimism as a correlate of decision-making styles in adolescence. SAGE Open, 2015;5(2):1-12.

25. Heppner MJ, Multon KD, Johnston JA. Assessing psychological resources during career change: development of the Career Transition Inventory. J Vocat Behav. 1994;44:55-74.

26. Sweeny K, Carroll PJ, Shepperd JA. Thinking about the future: is optimism always best? Curr Dir Psychol Sci. 2006;15:302-306.

27. Vuori J, Koivisto P, Jokisaari M, Salmela-Aro K, Mutanen P. Towards working life: effects of an intervention on mental health and transition to post-basic education. $J$ Vocat Behav. 2008;72(1):67-80.

28. Creed PA, Patton W, Prideaux LA. Predicting change over time in career planning and career exploration for high school students. J Adolesc. 2007;30(3):377-392.

29. Gushue GV, Scanlan KRL, Pantzer KM, Clarke CP. The relationship of career decision-making self-efficacy, vocational identity, and career exploration behavior in African American high school students. J Career Dev. 2006;33:19-28.

30. Lent RW, Brown SD, Larkin KC. Self-efficacy in the prediction of academic performance and perceived career options. J Couns Psychol. 1986;33(3):265-269.

31. Lopez FG, Ann-Yi S. Predictors of career indecision in three racial/ ethnic groups of college women. J Career Dev. 2006;33(1):29-46.

32. Wolfe JB, Betz NE. The relationship of attachment variables to career decision-making self-efficacy and fear of commitment. $C D Q$. 2004;52(4):363-369.

33. Ng TWH, Feldman DC. The school-to-work transition: a role identity perspective. J Vocat Behav. 2007;71(1):114-134.

34. Morrison EW. The school-to-work transition. In Feldman DC, editor, Work Careers: A Developmental Perspective. San Francisco: JosseyBass; 2002:126-158.

35. McArdle S, Waters L, Briscoe J, Hall D. Employability during unemployment: adaptability, career identity and human and social capital. J Vocat Behav. 2007;71:247-264.

36. Fugate M, Kinicki AJ, Ashforth BE. Employability: a psychosocial construct, its dimensions, and applications. J Vocat Behav. 2004;65(1):14-38.
37. Bergami M, Bagozzi RP. Self-categorization, affective commitment and group self-esteem as distinct aspects of social identity in the organization. Br J Soc Psychol. 2000;39:555-577.

38. Boros S. Organizational identification: theoretical and empirical analyses of competing conceptualizations. Cogn Brain Behav. 2008;12(1):1-27.

39. Turner JC, Hogg MA, Oakes PJ, Reicher SD, Wetherell MS. Rediscovering the Social Group: A Self-Categorization Theory. Oxford \& New York: Basil Blackwell; 1987.

40. Rust RT, Oliver RL. Service quality: insights and managerial implications from the frontier. In: Rust RT, Oliver RL, editors, Service Quality: New Directions in Theory and Practice. Thousand Oaks, CA: Sage publication; 1994:241-268.

41. Zehrer A, Crotts J, Magnini V. The perceived usefulness of blog postings: an extension of the expectancy disconfirmation paradigm. JTHM. 2011;32(1):106-113.

42. Appleton-Knapp SL, Krentler KA. Measuring student expectations and their effects on satisfaction: the importance of managing student expectations. J Mark Educ. 2006;28(3):254-264.

43. Arambewela R, Hall J. An empirical model of international student satisfaction. APJML. 2009;21(4):555-569.

44. McConnell AR. The multiple self-aspects framework: self-concept representation and its implications. PSPR. 2011;15(1):3-27.

45. Hirschi A. Career adaptability development in adolescence: multiple predictors and effect on sense of power and life satisfaction. $J$ Vocat Behav. 2009;74(2):145-155.

46. Gore S, Kadish S, Aseltine RH, Jr. Career centered high school education and post-high school career adaptation. Am J Community Psychol. 2003;32(1):77-88.

47. Skorikov VB Continuity in adolescent career preparation and its effects on adjustment? J Vocat Behav. 2007;70:8-24.

48. Skorikov VB, Vondracek FW. Positive career orientation as an inhibitor of adolescent problem behavior. J Adolesc. 2007;30:131-146.

49. Santisi G, Magnano P, Hichy Z, Ramaci T. Metacognitive strategies and work motivation in teachers: an empirical study. Procedia Soc Behav Sci. 2014;116:1227-1231.

50. Nauta MM. Career interests, self-efficacy, and personality as antecedents of career exploration. J Career Assess. 2007;15(2):162-180.

51. Gysbers NC. Facilitating career development through comprehensive guidance and counseling programs K-12. ACAPCD. 2007;1-2.

52. Nurmi JE, Aunola K, Salmela-Aro K, Lindroos M. The roles of success expectation and task-avoidance in academic achievement and satisfaction: three studies on antecedents, consequences and correlates. $C E d$ Psyc. 2003;28(1):59-90.

53. Heppner MJ. The career transition inventory. J Career Assess. 1991;6(2): 135-145.

54. Oliver RL. A cognitive model of the antecedents and consequences of satisfaction decisions. JMR. 1980;17(4):460-469.

55. Oliver RL. Cognitive, affective, and attribute bases of the satisfaction response. J Consumer Res. 1993;20:418-430.

56. Kim W, Jun HM, Walker M, Drane D. Evaluating the perceived social impacts of hosting large-scale sport tourism events: scale development and validation, Tour Manag. 2014;48:21-32.

57. Flynn L, Pearcy D. Four subtle sins in scale development: some suggestions for strengthening the current paradigm. Educ Psychol Meas. 2001;43(4):409-433.

58. Aron A, Aron EN, Smollan D. Inclusion of other in the self scale and the structure of interpersonal closeness. J Pers Soc Psychol. 1992;63(4):596-612.

59. Gachter S, Starmer C, Tufano F. Measuring the closeness of relationships: a comprehensive evaluation of the "Inclusion of the Other in the Self" scale. PLoS One, 2015;10(6):e0129478. http://doi.org/10.1371/ journal.pone.0129478.

60. Arbuckle JL, Wothke W. AMOS 4.0 User's Guide. Chicago, IL: Small Waters; 1999.

61. Byrne BM. Structural Equation Modeling with AMOS: Basic Concepts, Applications, and Programming. Mahwah, NJ: Lawrence Erlbaum, 2001. 
62. James LR, Mulaik SA, Brett JM. A tale of two methods. Organ Res Meth. 2006;9:233-244.

63. Shrout PE, Bolger N. Mediation in experimental and non-experimental studies: new procedures and recommendations. Psychol Methods. 2002;7(4):422-445.

64. Tabachnick BG, Fidell LS. Using Multivariate Statistics. 5th ed. Boston: Allyn \& Bacon; 2007.

65. Hu LT, Bentler PM. Cut-off criteria for fit indexes in covariance structure analysis: conventional criteria versus new alternatives. Struct Equ Model. 1999;6(1):1-55.

66. Bentler PM. Comparative fit indexes in structural models. Psychol Bull. 1990;107(2):238-246.

67. Hayes AF. Beyond Baron and Kenny: statistical mediation analysis in the new millennium, Commun Monogr. 2009;76:408-420.

68. Preacher KJ, Hayes AF. Asymptotic and resampling strategies for assessing and comparing indirect effects in multiple mediator models. Behav Res Methods. 2008;40(3):879-891.

69. Wong C, Hui C, Law KS. A longitudinal study of the job perception-job satisfaction relationship: a test of the three alternative specifications. J Occup Organ Psychol. 1998;71(2):127-146.

70. Hall DT. The protean career: a quarter-century journey. $J$ Vocat Behav. 2004;65:1-13.

71. Schmitt N, Oswald FL, Friede A, Imus A, Merritt S. Perceived fit with an academic environment: attitudinal and behavioral outcomes. J Vocat Behav. 2008;72(3):317-333.

72. Caza BB, Creary SJ. The construction of professional identity. 2016:1141. Available from: https://scholarship.sha.cornell.edu/articles/878/. Accessed January 29, 2016.
73. Platania S, Santisi G, Magnano P, Ramaci T. Job satisfaction and organizational well-being queried: a comparison between the two companies. Procedia Soc Behav Sci. 2015;19:1436-1441.

74. Seibert SE, Crant JM, Kraimer ML. Proactive personality and career success. J Appl Psychol. 1999;84(3):416-427.

75. Mayer JD, Salovey P. The intelligence of emotional intelligence. Intelligence. 1993;17(4):433-442.

76. Magnano P, Santisi G, Platania S. Emotional intelligence as mediator between burnout and organizational outcomes. IJWOE. 2017;8(4): 305-320.

77. Magnano P, Craparo G, Paolillo A. Resilience and emotional intelligence: which role in achievement motivation. IJPR. 2016;9(1):9-20.

78. Magnano P, Paolillo A, Platania S, Santisi G. Courage as a potential mediator between personality and coping. Personal Individ Differ. 2017;111:13-18.

79. Ginevra MC, Magnano P, Lodi E, et al. The role of career adaptability and courage on life satisfaction in adolescence. $J$ Adolesc. 2018; 62:1-8.

80. Magnano P, Platania S, Ramaci T, Santisi G, Di Nuovo S. Validation of the Italian version of the Mindfulness Organizing Scale (MOS) in Organizational contexts. TPM. 2017;24(1):45-64.

81. Vogus TJ, Sutcliffe KM. Organizational mindfulness and mindful organizing: a reconciliation and path forward. Acad Manag Learn Educ. 2012;11(4):722-735.

82. Weick KE, Sutcliffe KM. Mindfulness and the quality of organizational attention. Organ Sci. 2006;17(4):514-524.

83. Savickas ML. Life design: a paradigm for career intervention in the 21st century. J Couns Dev. 2012;90(1):13-19.
Psychology Research and Behavior Management

\section{Publish your work in this journal}

Psychology Research and Behavior Management is an international, peerreviewed, open access journal focusing on the science of psychology and its application in behavior management to develop improved outcomes in the clinical, educational, sports and business arenas. Specific topics covered in the journal include: Neuroscience, memory and decision making; Behavior

\section{Dovepress}

modification and management; Clinical applications; Business and sports performance management; Social and developmental studies; Animal studies. The manuscript management system is completely online and includes a very quick and fair peer-review system, which is all easy to use. Visit http://www. dovepress.com/testimonials.php to read real quotes from published authors. 